\title{
Sharia Business Unit Spin-off: Strategic Development Model of Sharia Banking in Indonesia
}

\author{
Iim Hilman ${ }^{1}$ \\ ${ }^{1}$ Stie Ekuitas School of Business, Jl. P.H. Hasan Mustopa No. 31 Bandung, Indonesia \\ Correspondence: Iim Hilman, Stie Ekuitas School of Business, J1. P.H. Hasan Mustopa No. 31 Bandung, \\ Indonesia. Email: iim.hilman@ekuitas.ac.id
}

Received: June 25, 2018

Accepted: July 2, 2018

Online Published: July 15, 2018

\begin{abstract}
Islamic bank in Indonesia in the last ten years shows a positive trend is quite impressive, the average asset growth of $30 \%$ is well above the average growth of conventional banks which only reached $15 \%$. The other side, if the terms of its contribution to the national banking system is still very small, as indicated by the achievement of market share of Islamic banks until the end of December 2016 reached only $5.30 \%$ of the total national banking assets. Regarding to the objective conditions, would need the appropriate business development strategy to boost growth and expand market share, so that Islamic banks can increase their role in national economic activities. Spin-Off sharia business unit owned by a conventional bank is one of the business development strategy offered by the Banking Act. This paper aims to identify and measure the effectiveness of the implementation of the spin-off business unit into a sharia/Islamic banks (Sharia Commercial Bank-SCB) that have been carried out by some Islamic banks in Indonesia. The results show that the growth rate of SCB business activity is better than Sharia Business Unit (SBU), but in terms of profitability and efficiency level of SBU is better than SCB.
\end{abstract}

Keywords: Spin-off, Sharia Business Unit, Business Srtategy, Full-Pledge Sharia, Conventional Bank.

\section{Introduction}

The beginning of the birth of sharia banking in Indonesia was marked by the birth of Bank Muamalat Indonesia (BMI) in 1992, as a commercial bank based on Islamic sharia (Al-Qur'an and Al-Hadith). His birth can not be separated from the initiative, determination and struggle of the scholars who are collected in the Indonesian Ulama Council (MUI) who want the establishment of Islamic banks in Indonesia, which in fact the majority Muslim community. Although if observed from the legal aspect of the existence of Islamic banks (syariah bank) is still very sumir, that is only based on the use of term / phrase "profit sharing" contained in Article 6 letter m Act (Law) no. 7 of 1992 on Banking, which states: "providing financing for customers on the basis of profit sharing principles, ....".

Further developments, sharia banking terms and new sharia principles are introduced in Law no. 10 of 1998 on Amendment of Law no. 7 of 1992 concerning Banking, that commercial banks are banks conducting conventional and / or sharia-based business activities which in their activities provide services in payment traffic. In that period, for approximately 7 years, practically BMI was the only commercial bank conducting business based on sharia principles, in the midst of competition with conventional commercial banks amounting to 238 banks with 7,661 offices at the end of December 1998 with total assets reached Rp 895.5 trillion (compared with total assets of sharia banks of Rp 400 billion). This shows that the development of sharia banks in Indonesia is not as expected. 
The birth of Law no. 10 of 1998 became a stronger foundation and a milestone for the development of sharia banking in Indonesia. Under the law, conventional commercial banks are given the opportunity to implement sharia services through the opening of Sharia (Islamic) Business Units and Sharia Branch Offices (SBO), as well as the opportunity to open sharia services in conventional branches (Office Channeling), and even to convert all of its business activities become sharia bank business activities. Not stopping there, the seriousness and alignment of the government to develop sharia banking in Indonesia, in 2008 in July was born Law no. 21 of 2008 concerning Sharia Banking, followed by the issuance of Bank Indonesia Regulation (PBI) No.11/3/PBI/2009 and Circular Letter of Bank Indonesia (SEBI) No. 11/9/DPbS concerning Sharia Commercial Banks, and PBI No.11/10/PBI/2009 concerning Sharia Business Unit. One of the provisions of the said regulation is a Conventional Commercial Bank (BUK) able to perform the Spin-Off of UUS which is owned by obtaining a license from Bank Indonesia first.

Since the establishment of the regulation, sharia banking has begun to show a very impressive development, shown by the end of July 2012 the number of Islamic Banks (BUS) of 11 units and UUS as many as 24 units supported by 2,038 offices. Total assets collected amounted to Rp 145.6 trillion, supported by Human Resources (SDI) as many as 25,630 people. Even until the end of December 2016 the number of BUS increased to 13 units with 1,869 offices, and UUS as many as 21 pieces with 332 offices. The amount of Third Party Funds (DPK) collected amounted to Rp 279,335 billion, the amount of financing that was disbursed was Rp 250,971, bringing the total assets to Rp 356,504 billion. In addition, there are 166 Shariah Rural Banks (BPRS) with 453 offices. The number of SDI (Human Resources) in the syariah banking industry increased to as many as 59,969 people. Fiqure 1 illustrates the composition of sharia banking assets based on bank types, namely BUS, UUS and BPRS.

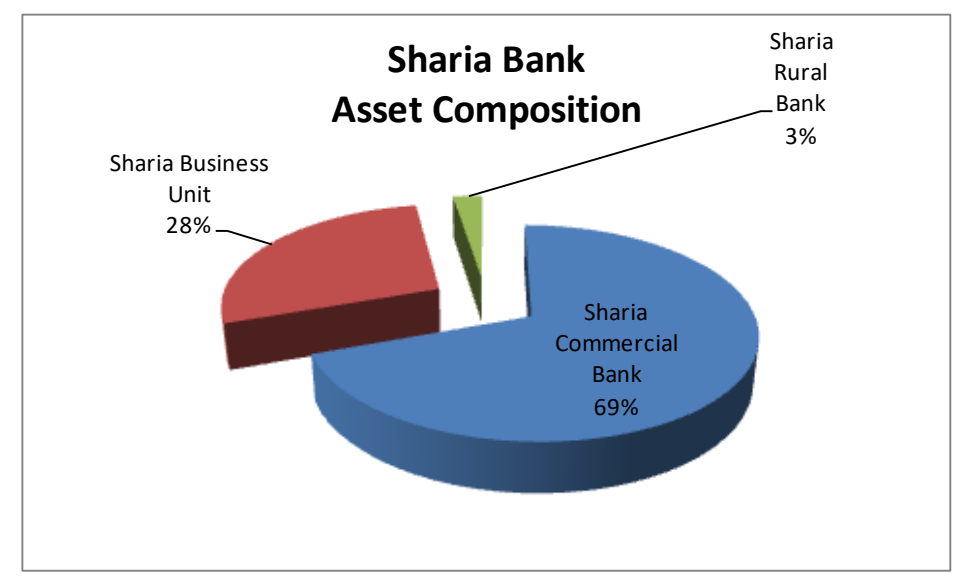

Figure 1 Asset Composition of Sharia Bank

Although the development of sharia banking up to now is quite encouraging, but if seen from its contribution to the national banking is still too small with a total market share of only 5.3\% (total national banking assets of Rp 6.729 trillion while Islamic banking assets of Rp 356 trillion) still far from the blue print target of $10 \%$ in 2018 (10 years post-birth Act No. 21 of 2008). This is a challenge for all stakeholders (actors, regulators, government, educational institutions, religious leaders and community leaders) to continue to improve the performance of sharia banking, in accordance with their respective fields, so that the contribution of sharia banking to the national economy is increasingly large and increasingly perceived benefit by society. Table 1.1 below shows the development of sharia banking for 10 years period 2017 s.d. 2016 . 
Table 1 Financial Performance Growth of SCB and SBU (Year, 2007 - Year, 2016)

\begin{tabular}{|c|c|c|c|c|c|c|c|c|c|c|c|}
\hline & & & & & & & & & \multicolumn{3}{|c|}{ (Rp billion) } \\
\hline $\begin{array}{c}\text { Business Activity } \\
\text { \& Financial } \\
\text { Performance }\end{array}$ & $\begin{array}{l}\text { Year } \\
2007\end{array}$ & $\begin{array}{l}\text { Year } \\
2008\end{array}$ & $\begin{array}{l}\text { Year } \\
2009\end{array}$ & $\begin{array}{l}\text { Year } \\
2010\end{array}$ & $\begin{array}{l}\text { Year } \\
2011\end{array}$ & $\begin{array}{l}\text { Year } \\
2012\end{array}$ & $\begin{array}{l}\text { Year } \\
2013\end{array}$ & $\begin{array}{l}\text { Year } \\
2014\end{array}$ & $\begin{array}{l}\text { Year } \\
2015\end{array}$ & $\begin{array}{l}\text { Year } \\
2016\end{array}$ & $\begin{array}{c}\text { Growth } \\
(\%)\end{array}$ \\
\hline \multicolumn{12}{|l|}{$\begin{array}{l}\text { Sharia Commercial } \\
\text { Bank (BUS) }\end{array}$} \\
\hline - Total Asset & 27.28 & 34.03 & 48.01 & 79.18 & 116.9 & 120.7 & 188.9 & 204.9 & 213.4 & 254.1 & 26,42 \\
\hline - Total Third Party & 6 & 6 & 4 & 6 & 30 & 05 & 75 & 61 & 23 & 84 & 21,46 \\
\hline Fund & 21.96 & 27.73 & 39.62 & 64.33 & 96.54 & 97.77 & 148.9 & 170.7 & 174.8 & 206.4 & 18,55 \\
\hline - Total Financing & 6 & 4 & 4 & 5 & 8 & 9 & 93 & 23 & 95 & 07 & 2,77 \\
\hline - Paid-up Capital & 20.71 & 26.10 & 34.45 & 56.35 & 83.70 & 95.18 & 149.1 & 148.4 & 154.5 & 178.0 & 0,15 \\
\hline - Profit/Loss & 7 & 9 & 2 & 7 & 4 & 7 & 39 & 25 & 27 & 43 & 0,00 \\
\hline - Number of BUS & 1.001 & 1.701 & 1.946 & 5.965 & 6.611 & 6.911 & 8.181 & 19.58 & 23.40 & 26.97 & 0,19 \\
\hline - Number of Office & 602 & 637 & 794 & 1.275 & 2.119 & 2.864 & 2.681 & 5 & 9 & 5 & 5,31 \\
\hline - Number & 3 & 5 & 6 & 11 & 11 & 11 & 11 & 822 & 977 & 1.420 & \\
\hline \multirow[t]{4}{*}{ Employee (SDI } & 398 & 576 & 711 & 1.215 & 1.390 & 1.532 & 1.998 & 12 & 12 & 13 & \\
\hline & 4.311 & 6.609 & 10.34 & 15.22 & 21.82 & 22.62 & 26.71 & 2.163 & 1990 & 1.869 & \\
\hline & & & 8 & 4 & 0 & 7 & 7 & 41.39 & 51.41 & 51.11 & \\
\hline & & & & & & & & 3 & 3 & 0 & \\
\hline \multicolumn{12}{|l|}{ Sharia Business } \\
\hline - Total Asset & 9.252 & 15.51 & 18.07 & 18.33 & 28.53 & 34.96 & 53.30 & 67.38 & 82.83 & 102.3 & 10,55 \\
\hline - Total Third Party & 6.045 & 9 & 6 & 3 & 6 & 2 & 1 & 3 & 9 & 20 & 7,51 \\
\hline Fund & 7.227 & 9.118 & 12.64 & 11.70 & 18.86 & 23.23 & 34.54 & 47.13 & 56.28 & 72.92 & 7,33 \\
\hline - Total Financing & 87 & 12.09 & 8 & 2 & 7 & 9 & 1 & 6 & 0 & 8 & 0,16 \\
\hline - Paid-up Capital & 0 & 0 & 12.43 & 11.82 & 18.95 & 25.72 & 34.98 & 51.75 & 59.46 & 71.04 & 0,00 \\
\hline - Profit/Loss & 26 & (52) & 5 & 4 & 2 & 3 & 3 & 2 & 2 & 4 & 0,00 \\
\hline - Number of BUS & 170 & 0 & 311 & 303 & 425 & 566 & 549 & 1.227 & 1.324 & 1.529 & 0,04 \\
\hline - Number of Office & 2.266 & 27 & 0 & 0 & 0 & 0 & 0 & 0 & 0 & 0 & 0,48 \\
\hline - Number & & 214 & 25 & 23 & 23 & 24 & 23 & 22 & 22 & 21 & \\
\hline \multirow[t]{3}{*}{ Employee (SDI } & & 2.562 & 287 & 262 & 312 & 471 & 590 & 320 & 311 & 332 & \\
\hline & & & 2.296 & 1.868 & 2.067 & 3.003 & 11.51 & 4.425 & 4.403 & 4.487 & \\
\hline & & & & & & & 1 & & & & \\
\hline
\end{tabular}

Source: BI and OJK, Indonesia Banking Statistics, Dec. 2016 (processed)

Judging from the development of Islamic banks, there is an interesting phenomenon to be observed, namely the development of financial performance BUS much better when compared with the development of financial performance UUS.Where the development over the last 10 years (2007 s.d. 2016), BUS shows the average development of financial performance of $26.42 \%$ per year, much better than the average development of UUS of $10.55 \%$ per year. Of the 13 BUS, most of its formation is through the spin-off pattern of UUS into BUS, either by establishing a new legal entity or acquisition and conversion. Based on the exposure and phenomenon, the 
purpose of this research is to find out how the spin-off mechanism is implemented and whether the spin-off strategy has had a positive impact for the development of national sharia banking.

The composition of third party funds was dominated by mudharabah deposits. Related to results research by Hilman (2016), that the mudharabah deposits growth indicate that the level of revenue sharing has the most influence on the amount of mudharabah deposit. This shows that the profit motive is still one of the main motives for customers to keep their funds in sharia banks.

\section{Literature Review}

\subsection{Corporate Strategy and Business Strategy}

The strategy derives from the Greek word, strategos (stratos = army or military, and agos = lead) has the meaning of art of war, or else it can be defined strategy is the science of planning and mobilization of resources for large-scale operations, launching forces in the most ready position profitable before attacking the opponent (Hutabarat and Huseini, 2012). While Johnson \& Scholes (1997) states that strategy as the direction and long-term coverage of the organization to gain excellence through resource configuration in a changing environment to achieve market needs and meet the expectations of stakeholders. Mintzberg (1994) defines a strategy as a 5P, a strategy as a perspective, position, planning, pattern of activity, and deception (ploy) is a secret trick.

Strategy as the direction and long-term coverage of the organization to gain excellence through resource configuration in a changing environment to achieve market needs and meet the expectations of stakeholders. (Gerry Johnson \& Kevan Scholes, in Hutabarat and Huseini, 2012). Furthermore, Henry Mintzberg in Hutabarat (2012) defines a strategy as a 5P, namely: as a perspective, as a position, as a plan, as a pattern of activity, and as a ploy of secret tricks. From the above understanding, the strategy is a plan of a series of maneuvers, including all visible and invisible elements, to ensure success in achieving goals.

A corporate strategy is a corporate-level strategy that houses multiple corporate or corporate groups, or at the enterprise level that manages the business unit and serves several different industries. While the business strategy is used for companies that are in a group of companies, stand-alone companies or strategic business units (SBU) within a company. In certain situations, the business strategy with corporate strategy becomes unified, that is in the corporation that operates, and in other situations, separate and is a harmonious derivation (Hutabarat and Huseini, 2912).

Wheelen \& Hunger (2015) argues that corporate strategy is primarily about the choice of direction for a firm as a whole and the manegement of its business or product portfolio. Corporate strategy, therefore, includes a decision on the flow of financial and other resources to and from a compani's product lines and business units. A corporation's directional strategy is composed of three general orientations (called grand strategies): 1) growth strategies expand the company's activities, 2) retrenchment strategies reduce the company's level of activities. Strategic management is a process for determining the direction and objectives of the organization in the long run and methods to achieve it through the development of systematic planned formulation and implementation of the system (Susanto, 2014). Business strategies may include geographic expansion plans, business diversification plans, acquisitions, product development, joint ventures, market penetration, market development, and so on. Strategic management is a set of managerial decisions and actions that help determine the long-term performance of an organization. It includes environmental scanning (both external and internal), strategy formulation (strategic or long-range planning), strategy implementation, and evaluation and control. Originally called business policy, strategic management has advanced substatially with the concentrated efforts of researchers and practitioners. Today we recognize both a science and an application of strategic management techniques. (Wheelen and Hunger, 2015). Benefit of strategic management are: 1) a clearer sense of strategic vision for the 
firm, 2) a sharper focus on what is strategically important, and 3) improved understanding of rapidly changing environment.

\subsection{Business Model and Bank Business Model}

The business model has attracted great attention from various academics and practitioners. Some experts define business models as follows. Giorgetti (1998) defines a business model as a reference model that is the basis for a new type system that has advantages over the previous approach. This system can explain the deficiencies / weaknesses of the previous system and show how to overcome the shortcomings / weaknesses of existing systems. While Cristensen (2001), states that the business model as a source of all competitive advantage owned by an organization that differentiates it with the company's positioning of products in the same industry. Another notion of Chesborough in Zott and Amit (2009) defines the business model as an activity-based chain structure, creating value by defining a series of activities ranging from raw materials to raw materials to final customers, at where a predetermined value is added to the overall activity.

Some of these notions are an extension of generic theory about business models, as has been suggested by Timmer (1998), Tapscott et al. (2000), Kraemer et al. (2000). Furthermore, a comprehensive understanding of the business model proposed by Osterwalder and Pigner (2009) suggests that business models illustrate the rationale for how organizations create, deliver, and capture the values held by organizations that can be explained through 9 (nine) main generic elements / pillars (9 building blocks of business model), such as customer segment, value preposition, delivery channel, customer relationship, revenue stream, key resources, key activities, key partnership, and cost structure.

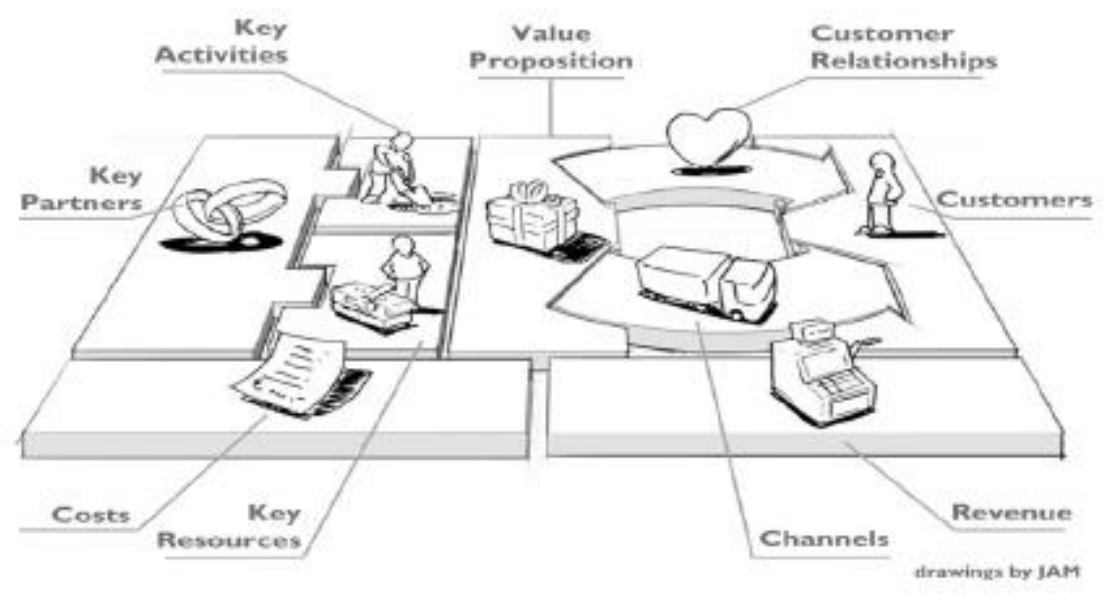

Figure 2 Nine Element of Business Model

The diversification of the business model and business activities of the bank is driven by several factors: a) the bank obtains valuable information related to key bank customers that may be very useful for future prospects and complementing other business activities (Sharpe, 1990; Diamond, 1991, Rajan (1992), b) to reduce risks and obtain economic of scope banks to apply some business models (Diamond, 1984); and c) to win interbank rivalries, the bank adopts a different business model with its competitors bank and get as many customers as possible the number.

From the existing literature, it can be recapitulated several types of business models applied in the banking industry both abroad and within the country. The types of business models can be grouped based on activity, financial purpose, customer segment, special purpose, and channel, as illustrated below. 


\begin{tabular}{|c|c|}
\hline Activity & 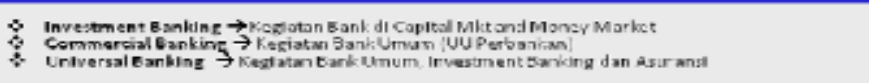 \\
\hline $\begin{array}{l}\text { Financial } \\
\text { Purpose }\end{array}$ & 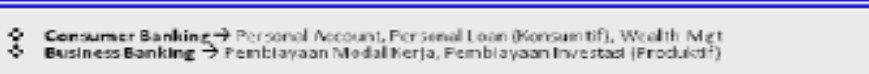 \\
\hline $\begin{array}{l}\text { Customer } \\
\text { Segment }\end{array}$ & 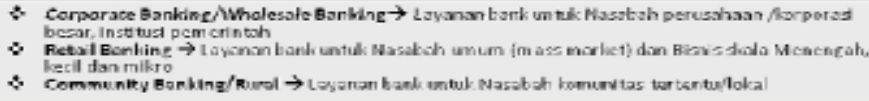 \\
\hline $\begin{array}{l}\text { Special } \\
\text { Purpose }\end{array}$ & 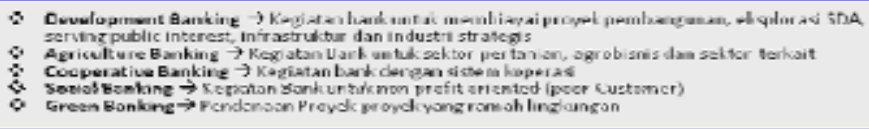 \\
\hline Channel & 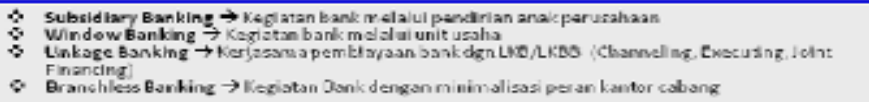 \\
\hline
\end{tabular}

Figure 3 Types of Business Models in the Banking Industry

The establishment of a Sharia Business Unit (UUS) by a Conventional Commercial Bank is a form of implementation of the Window Banking model in Indonesia. Window banking is an attempt by commercial banks to penetrate the market by providing banking and financial services to customers who can not be served by existing commercial banks, such as collided by rules and principles embraced by customers.

\subsection{Spin-off Definition}

The spin-off or hive-off terminology which in Dutch law is called splitzing, or in Australia known as demerger, is new to the legislation in Indonesia. Under the Limited Liability Company, the term spin-off is called separation, which is a legal act done by the company to separate the business resulting in all assets and liabilities of the company being transferred because the law to 2 (two) or more companies or part of the assets and liabilities of the company is due to the law to 1 (one) company or more.

The Black Law Dictionary defines a spin-off as a corporate divestiture in which a division of a corporation is independent of the company and stock of the company is distribute to the corporation's shareholders. While Rusdisui in Geersing (2007) states that: "A spin-off can be best described as a distribution of a majority (often $80 \%$ or more) of the shares of the subsidiary to the parent's shareholders. In case of a $100 \%$ spin-off, the divested company becomes a completely independent company, with initially the same shareholders as the parent company. After the transaction, the former parent shareholders have two securities. The shares of the parent company and the shares of the divested spinoff company". While in Law no. 21 of 2008 (Islamic Banking Law) found the term separation is the separation of a bank into two or more business entities in accordance with applicable provisions.

From some definitions above, it can be seen that separation or spin-off is a corporate action which aims to separate the former from within a legal entity, then it "splits" or "divides" by the legal recognition of the division or its cleavage. The condition of the division or division of a legal entity in the form of a limited liability company shall begin with the will of the parties contained in the agreement or agreement made by the parties having authority in the organ of the company.

Spin-off or separation as one part of corporate restructuring, is basically the act of the parent company in the separation of businesses have the same motivation with the establishment of a subsidiary. This separation will have implications on the formation of group companies or the incidence of control of one company to another company. The requirement of the formation of a group company from separation is that one company acts as a holding company controlling one or more other companies of juridical separation (Sulistiowati, 2009).

\subsection{Purpose and Benefit of Spin-Off}

Some considerations and reasons why company's spin-off includes management reasons, capital market factors, 
risks, tax benefits, or regulatory reasons. Some parent companies decide to spin off subsidiaries because they believe that their business is not accurately assessed in the capital market. By spin-off allows each company to obtain capital consistently based on its own activities or each company in raising capital in accordance with the way the capital market affects the business of each company.

Parent company spin off subsidiaries to protect companies against certain risks, which are generally to stabilize the parent company's revenue.Spin-offs are risky to finance expansion based on their own tariffs of growth and projection. Spin-offs can attract new investors to spin-off companies and can increase the value of parent companies, because subsidiaries are no longer associated with it.

Spin-offs can alleviate the management problems of both parent companies and subsidiaries (spinoff results), since the two companies often have different interests. Parent companies typically have large operations that are unable to provide the management, finances and resources needed by subsidiaries to continue their business growth, as they focus more on core enterprise needs. Therefore, with spin-off management, finance, and resource issues in the subsidiary companies can be managed, implemented, and able to make their own decisions. The parent company can concentrate on its business activities and not burdened by the spin-off company, since the two companies are juridically separate (Tisnawan, 2009).

Through spin-offs can improve the company's performance and improve the company's management discipline. Aron (1991) argues that spin-offs benefit the company. After many spin-offs of equity securities are traded, managerial productivity gets better than when the two companies are still joining, so the company can provide better incentives for the company's management based on the individual company's stock price. Habib and Johnson (1997), argue that spin-offs improve quality, the prices of traded securities, have increased from the expected. In addition, spin-offs also have benefits or advantages such as low cost in terms of loans, savings on administrative costs, and reduced cost of spending centrally. In the restructuring of the spin-off, the company's spinoff business development is borne by the new owner of the company, even in making decisions, the parent company must convince and motivate the spinoff to take the risk and make the company successful.

\subsection{Spin-Off Types and Consequences}

Limited Company Act (Act No. 40 of 2007) Article 135 states that separation or spin-off is differentiated from pure spin-off and quasi-spin-off. Pure separation is a separation that results in the entire assets and liabilities of the company being transferred by law to two or more other companies that accept the transition and the company which makes the separation is subject to law. While improper separation resulted in some of the assets and liabilities of the company to be transferred because the law to other or more companies that received the transfers and the company that did the separation still exist.

Based on the definition, it clearly shows that the separation of assets and liabilities from a company into an independent new company (separate entity) is an essential element in the spin-off process. In practice, the separation of such assets and liabilities is generally the separation of a particular business unit (division) into a new company whose business activities can be the same or different from the original company. Referring to Sharia Banking Law (Law No. 21 of 2008) that the sharia bank law form whether the new establishment or separation result is confirmed must be in the form of Limited Liability Company (PT). Furthermore, it is affirmed that: "In the case of a Conventional Commercial Bank having a UUS whose asset value has reached at least 50\% (fifty percent) of the total value of its parent bank assets, or 15 (fifteen) years since the enactment of this Law, the Conventional Commercial Bank shall be obliged to make the Separation of UUS into a Sharia Commercial Bank "(article 68 paragraph 1 of Law No. 21 of 2008 on Sharia Banking).

\section{Methodology and Data}

This research uses descriptive and comparative method, where this research answers two questions that is how 
www.cribfb.com/journal/index.php/ijibfr International Journal of Islamic Banking and Finance Research Vol. 2, No. 2; 2018 and what. According Sugiyono (2012) states, that the descriptive method is a method used to describe or analyze a research result but not used to make wider conclusions. While the comparative method is a study comparing the existence of one or more variables in two or different samples, or at different times.

The method used in this research is quantitative descriptive approach. The data used is secondary data as well as the results of previous research related to the study. Data collection techniques used is a literature study where researchers conducted research through library materials. Library of materials that researchers get secondary data relating to the research conducted. The quantitative data collected from financial report publications of Sharia Commercial Bank and Sharia Business Unit period 2007 - 2016. The data is sourced from Islamic Banking Statistics published by Bank Indonesia (BI) and Financial Services Authority (OJK), as well as the financial statements of Islamic banks.

\section{Results and Discussion}

Since the issuance of the provisions concerning the separation of business units or spinoff UUS (Law No. 40 of 2007 on Limited Liability Companies and Law No. 21 of 2008 on Sharia Banking), up to now there are 13 Suariah Commercial Banks (BUS), of which 7 BUS is the result of spin-off UUS, namely: PT. Bank BRI Syariah, PT. Bank Syariah Bukopin, PT. Bank Jabar Banten Syariah, PT. Bank BNI Syariah, PT. Bank BCA Syariah, PT. Bank Aceh Syariah, and PT. Bank Tabungan Pensiunan Nasional Syariah, as shown below.

Table 2 Profile of Sharia Commercial Bank

\begin{tabular}{|c|c|c|c|}
\hline No. & Name of Bank & Operational & Way of Establishment \\
\hline 1. & PT. Bank Muamalat Indonesia & May, 1992 & Establishment of new Sharia Commercial Bank (SCB). \\
\hline 2. & PT. Bank Syariah Mandiri & November, 1999 & $\begin{array}{l}\text { Acquisition and conversion of PT. Bank Susila Bakti } \\
\text { (Conventional Commercial Bank-CCB) becames new SCB. }\end{array}$ \\
\hline 3. & PT. Bank Mega Syariah & July, 2004 & $\begin{array}{l}\text { Acquisition and conversion of PT. Bank Umum Tugu (CCB) } \\
\text { becames new SCB. }\end{array}$ \\
\hline 4. & PT. Bank Bukopin Syariah & October, 2008 & $\begin{array}{l}\text { Spin-off Sharia Business Unit (SCB) Bukopin, acquisition and } \\
\text { conversion of PT. Bank Persyarikatan (CCB). }\end{array}$ \\
\hline 5. & PT. Bank BRI Syariah & January, 2009 & $\begin{array}{l}\text { Spin-off SCB BRI, acquisition and conversion of PT. Bank Jasa } \\
\text { Arta (CCB). }\end{array}$ \\
\hline 6. & PT. Bank Panin Syariah & October, 2009 & Acquisition of PT. Bank Harfa (CCB) becomes new SCB. \\
\hline 7. & PT. Bank Victoria Syariah & February, 2010 & Conversion of PT. Bank Swaguna (CCB) becomes new SCB.. \\
\hline 8. & PT. Bank BCA Syariah & March, 2010 & $\begin{array}{l}\text { Spin-off SBU BCA, acquisition and conversion of PT. Bank } \\
\text { Utama Internasional Bank (CCB) becomes new SCB. }\end{array}$ \\
\hline 9. & PT. Bank Jabar Banten Syariah & May, 2010 & Spin-off SBU Bank Jabar Banten, and establish of new SCB. \\
\hline 10. & PT. Bank BNI Syariah & June, 2010 & Spin-off SBU Bank BNI, and establish new SCB. \\
\hline 11. & PT. Maybank Syariah Indonesia & October, 2010 & $\begin{array}{l}\text { Conversion of PT. Bank Maybank Indocorp (CCB) becomes } \\
\text { new SCB. }\end{array}$ \\
\hline 12. & PT. Bank BTPN Syariah & May, 2014 & $\begin{array}{l}\text { Spin-off SBU PT. Bank BTPN, acquisition and conversion of } \\
\text { PT. Bank Sahabat Purba Danarta (CCB) becomes new SCB. }\end{array}$ \\
\hline 13. & PT. Bank Aceh Syariah & September, 2016 & $\begin{array}{l}\text { Spin-off SBU and conversion of PT. Bank Aceh (CCB) becomes } \\
\text { new SCB. }\end{array}$ \\
\hline
\end{tabular}

Source: From various sources (processed by author)

Of the 13 (thirteen) existing Sharia Commercial Banks, most of its founding was initiated with the opening of SBU by Conventional Commercial Bank as its parent bank. This shows that SBU spin-off policy is an option 
that is implemented as a strategy of developing sharia banking.

\subsection{Spin-off Implementation Mechanism}

Spin-off is one form of corporate action whose implementation is regulated in Law no. 40 concerning Limited Liability Company in Article 126, therefore its implementation shall be approved by the General Meeting of Shareholders (GMS). The implementation of the spin-off shall be executed by the board of directors, previously consulted with the creditors and approving it, which shall observe: a) a corporation, minority shareholder; b) the creditor and other partners of the company; and c) society and healthy competition in doing business.

Spin-off procedures include the following steps: 1) preparation of the company's separation, including: a) drafting the separation plan, b) the separation plan must be announced to the public through mass media, c) the creditor may file an objection; 2) the separation of the company must be based on the GMS; 3) minority shareholders who do not agree may sell their shares to the company; 4) the act of separation of the company is a legal act; 5) report to the Minister of Law and Human Rights; and 6) announced the separation of the company in the mass media. The implementation scheme of the separation can be illustrated as shown below.

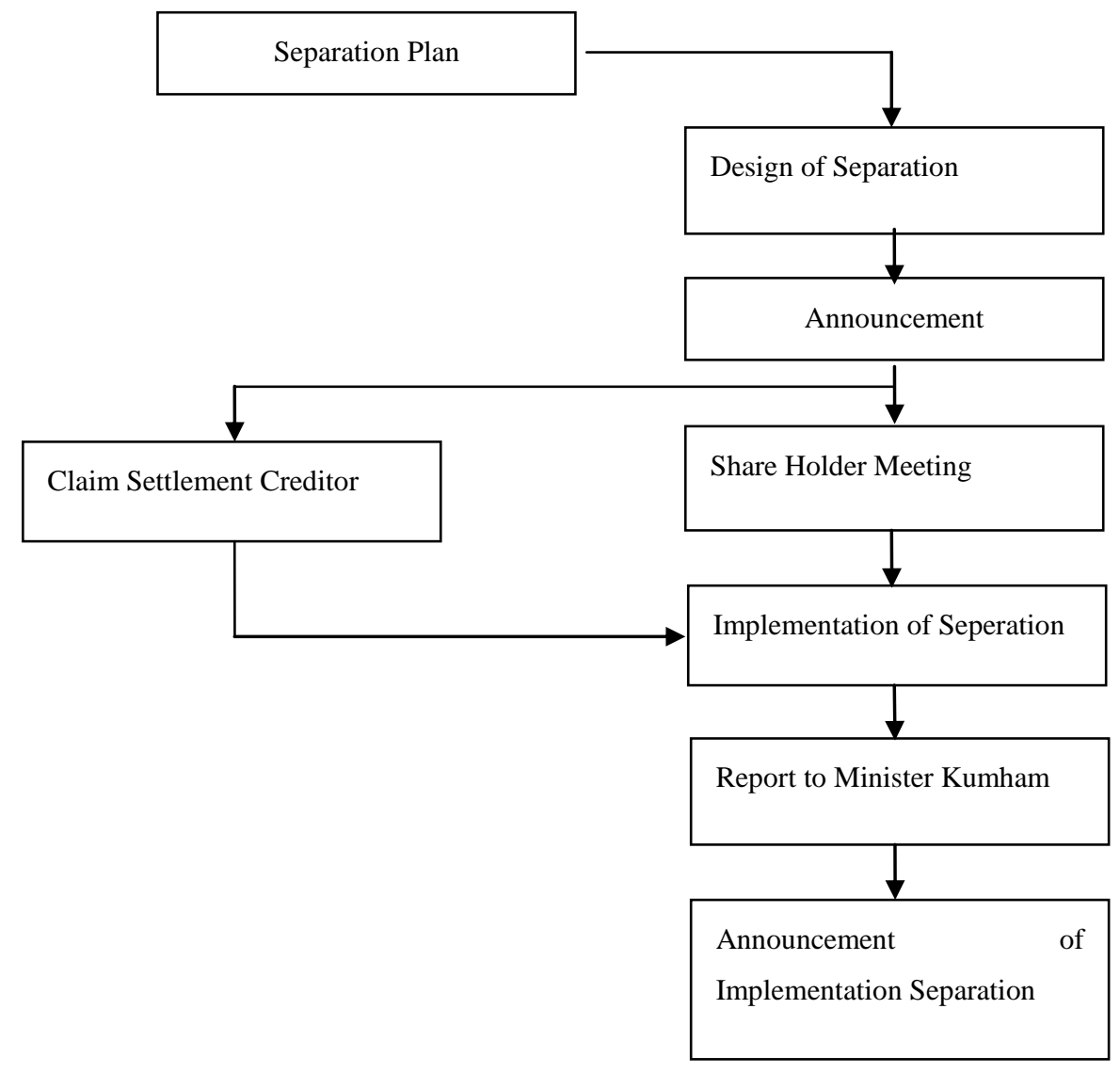

Figure1 Spin-off Implementation Scheme

Regarding the spin-off mechanism of UUS has been regulated specifically in Bank Indonesia Regulation (PBI) Number 11/01 / PBI / 2009. (see Chapter IX Articles 40-54). It should be noted that PBI No.11 / 10 / PBI / 2009 concerning Sharia Business Unit. According to Article 41 there are two ways of separating UUS from BUK, first by establishing a new Sharia (BUS) Commercial Bank; or second by transferring UUS rights and obligations to existing BUS. Firstly, the separation of the UUS by way of the establishment of a new BUS can only be done with a permit from Bank Indonesia (now the Financial Services Authority - OJK). Paid up capital of at least Rp500,000,000.00 (five hundred billion rupiah). If the paid-up capital is insufficient, the addition may be made in cash and / or land and building used for the operation of the BUS resulting from the separation. The paid-up 
capital of BUS resulting from the separation shall be increased to a minimum of Rp 1,000,000,000,000.00 (one trillion rupiah) not later than 10 (ten) years after the BUS business license is granted.

The granting of BUS's license for the establishment of BUS resulting from the separation shall be conducted in 2 (two) phases namely (a) approval in principle, namely approval to prepare for the establishment of BUS resulting from separation; and (b) a business license, namely a license granted after the separation of BUS is ready for operational activities. It is important to note that if the principle permit has been granted to BUK, but within 6 months after the principle permit has been granted, BUK has not yet applied for a BUS license of the result of separation, the principle approval has been granted. Therefore, BUK must prepare all necessary requirements to the maximum extent possible.

The second way of separation, namely the separation of UUS by transferring rights and obligations to the existing BUS can only be done with the approval of Bank Indonesia (now OJK). If the approval of the transfer plan has been obtained, the BUK holding UUS shall be obliged to announce it in a national newspaper within no later than 10 (ten) days and transfer the right and obligation of UUS to BUS no later than 30 (thirty) days after the date of the approval of the transfer. If within 30 days of transfer of UUS's right and obligation to BUS of recipient of separation has not been done then the approval given will be reviewed. Then the recipient of the separation must also report the financial condition after receiving the transfer of UUS rights and obligations no later than 10 (ten) days after the date of execution. It is important to note that the separation of UUS from BUK by transferring UUS rights and obligations to existing BUSs may only be made to BUSs which have ownership relationship with BUK that owns UUS.

\subsection{Implementation Model of SBU Spin-off}

Referring to the applicable provisions, the UUS Spin-Off can be implemented by transferring rights and obligations to an existing BUS or by establishing a new BUS, the following two spin off models are implemented by PT. Bank BRI Syariah and PT. Bank Jabar Banten Syariah.

\subsubsection{Spin-off Model UUS PT. Bank BRI}

Implementation of spin-off UUS PT. Bank BRI is done by acquiring a conventional Commercial Bank (BUK), namely PT. Bank Jasa Arta by PT. Bank BRI, then BUK of the acquisition result is converted to a Sharia (BUS) Commercial Bank with the name of PT. Bank BRI Syariah. The next step is PT. Bank BRI transferred all the assets and liabilities of UUS PT. Bank BRI to PT. Bank BRI Syariah. The implementation mechanism is shown in Figure 2 below.

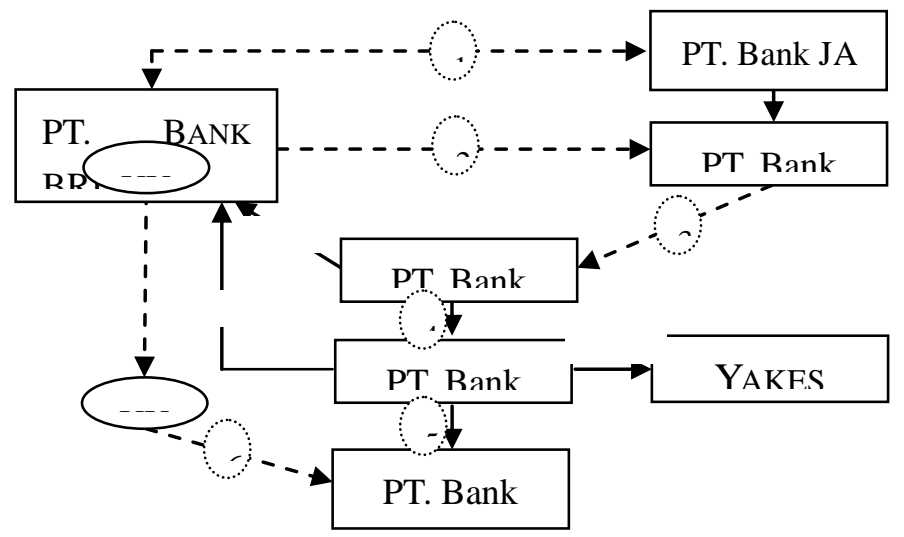

Gambar 2 Spin-Off Scheme of SBU PT. Bank BRI

\section{Caption}

1 is PT. Bank BRI negotiates with Shareholders of PT. Bank Jasa Arta

2 and 3 is the acquisition of $100 \%$ shares of PT. Bank Jasa Arta by PT. Bank BRI

4 is $99.99 \%$ share ownership composition of PT. Bank BRI and 0.01\% Yakes BRI 
5 is the conversion of PT Bank Jasa Arta to PT. Bank BRI Syariah

6 is the transfer of UUS's assets and liabilities (spin-off) to PT. Bank BRI Syariah

\subsubsection{Spin-off Model UUS PT. Bank Jabar Banten}

Implementation of spin-off UUS PT. Bank Jabar Banten conducted by establishing a new Sharia Bank (BUS) new, namely PT. Bank Jabar Banten Syariah by PT. Bank Jabar Banten with PT. Banten Global Development as founding partner, with $95 \%$ and 5\% share ownership composition. The next step is PT. Bank Jabar Banten transferred all the assets and liabilities of UUS PT. Bank Jabar Banten to PT. Bank Jabar Banten Syariah. The implementation mechanism is shown in Figure 4.3 below.

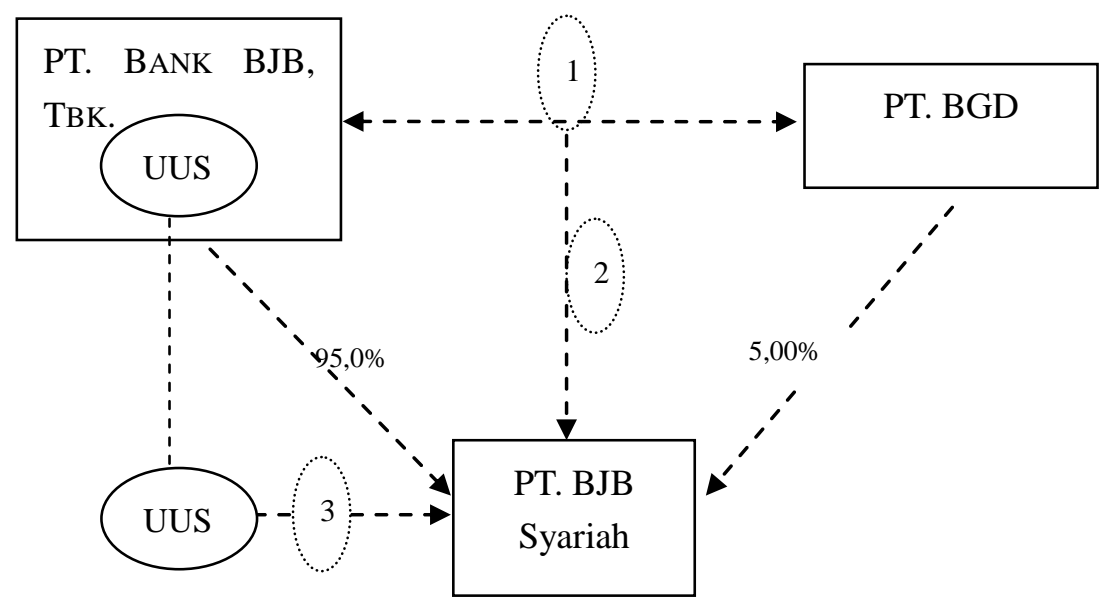

Figure 3 Spin-off Scheme of SBU PT. Bank Jabar Banten

\section{Caption:}

1 is PT. Bank Jabar Banten to negotiate with founding partner of PT. Banten Global Development to establish BUS

2 is 95\% share ownership composition of PT. Bank Jabar Banten and 5\% PT. Banten Global Development

3 is the implementation of spin-off UUS PT. Bank Jabar Banten to PT. Bank Jabar Banten Syariah

\subsection{Human Resource Policy (Sumber Daya Insani - SDI)}

Elements of SDI become a factor that is not less important to note in addition to business and operational aspects. With the implementation of the spin-off UUS will usually happen some new problems that must be addressed, so as not to disrupt the performance of banks after the spinoff. Issues experienced by BUS spin-off results such as the difficulty of changing the mindset from BUK to BUS, the difference in the competence of sharia banking between the conventional bank and the former UUS. The shortage of SDI to fill the existing positions, bringing together the SDI system, competence, performance standards, work culture, reward system which recently experienced by many sharia banks.

Therefore, post-spin-off BUS must optimize the function of SDI in order to face the challenges that will be faced for future development.Table 3 is an SDI strategy undertaken by several banks implementing the UUS spin-off.

Table 3 Human Resources Strategy

\begin{tabular}{cll}
\hline No. & Name of Bank & \multicolumn{1}{c}{ Human Resources Strategy } \\
\hline 1. & Bank BRI Syariah & Selection of all employees of the acquired bank in accordance \\
& with the passing grade \\
& - & SBU employees are given the right to choose whether to join the \\
& SCB or remain as an employee of the parent bank \\
& - & Recruit many new employees (pro hire) \\
\hline
\end{tabular}


- Old bank employees become a minority.

2. Bank BJB Syariah

- SBU employees are given the choice of whether to join the SCB or remain as an employee of the parent bank.

- Selection of interested parent bank employees

- The transition of the status of a parent bank employee to a BUS employee is made in a tripartite agreement (the holding bank-employee-SCB)

- Official 30\% elite officials come from outside (pro hire).

\begin{tabular}{|c|c|c|}
\hline 3. & Bank BCA Syariah & $\begin{array}{l}\text { - Maintain all employees of the acquired bank } \\
\text { - Board of Directors of the parent bank and new recruit (pro hire). }\end{array}$ \\
\hline 4. & Panin Bank Syariah & $\begin{array}{l}\text { - Lay-off of all employees of the acquired bank } \\
\text { - Recruit new employees including board of directors. }\end{array}$ \\
\hline
\end{tabular}

Source: From various sources (processed by author)

\subsection{Benefits of Spin-off Implementation}

Based on the results of the study on the implementation of Spin-off UUS Bank Jabar Banten to PT. Bank Jabar Banten Shariah conducted by first establishing a new Legal Entity with the name of PT. Bank Jabar Banten Syariah by PT. Regional Development Bank of West Java and Banten (Bank Jabar Banten), and Spin-Off UUS Bank BRI by first passing the acquisition and conversion of Bank Jasa Arta to BUS under the name of PT. Bank BRI Syariah, here are the benefits gained from the implementation of spin-off for the parent bank, UUS, employees and customers.

Table 4 Benefits of Spin-off

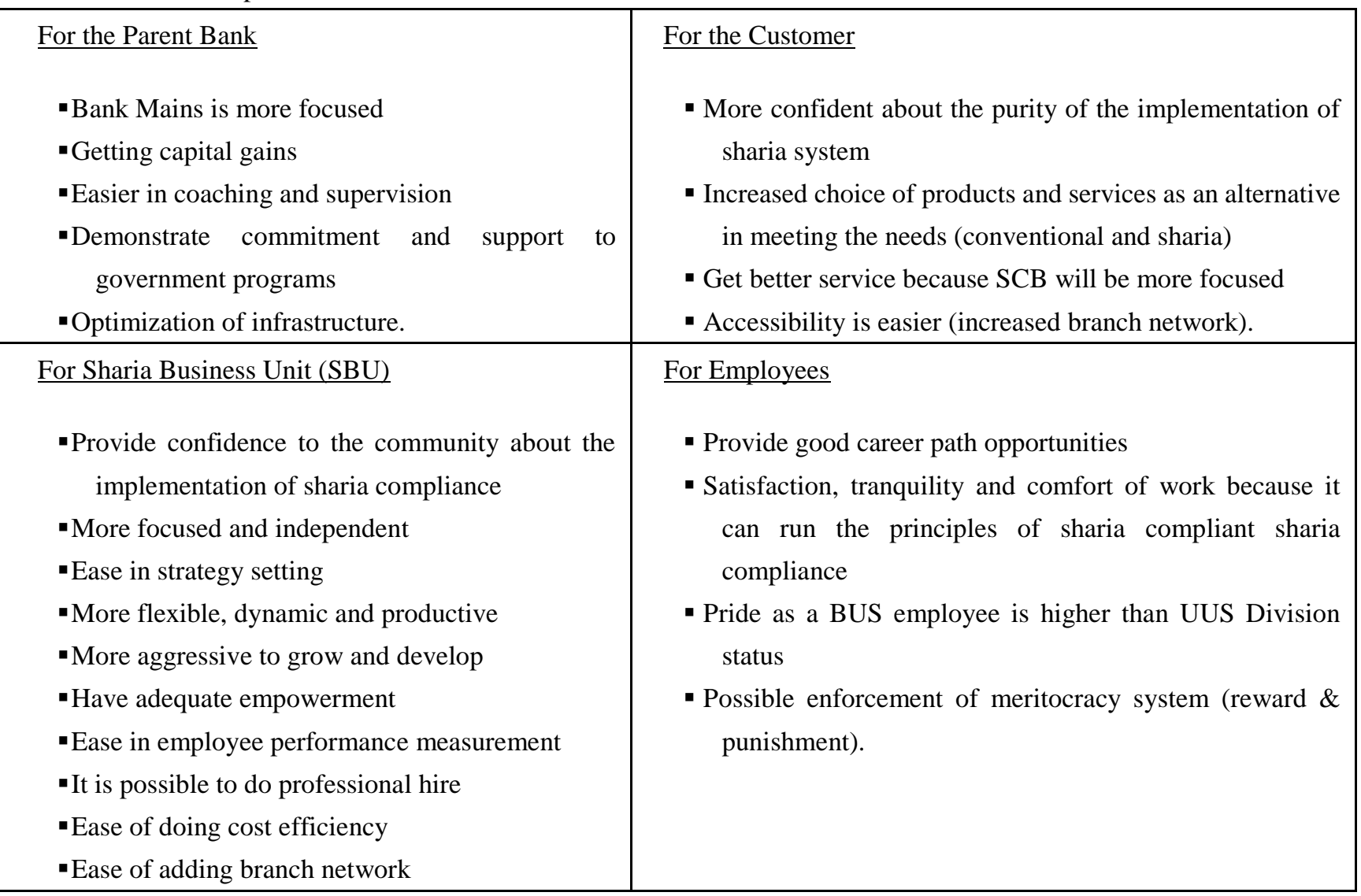

Source: Document of Spin-off Bank Jabar Banten Syariah (2010) 
4.4 Comparison of SCB Performance with SBU

As a result of comparative study on the performance of Sharia Commercial Bank (BUS) with Unis Usaha Syariah (UUS), Table 5 shows the financial performance of BUS and UUS for the period of 10 years (2007 2016).

Table 5 Comparative Financial Performance of Sharia Commercial Banks with Sharia Business Unit (period 2007 - 2016)

\begin{tabular}{|c|c|c|}
\hline Financial Performance & $\begin{array}{c}\text { Sharia Commercial Bank (SCB) } \\
\text { (Average) }\end{array}$ & $\begin{array}{c}\text { Sharia Business Unit (SBU) } \\
\text { (Average) }\end{array}$ \\
\hline Total Asset & $26,42 \%$ & $10,55 \%$ \\
\hline Third Party Funds (TPF) & $21,46 \%$ & $7,51 \%$ \\
\hline Financing & $18,55 \%$ & $7,33 \%$ \\
\hline Profit/Loss & $0,15 \%$ & $0,16 \%$ \\
\hline Financing to Deposit Ratio (FDR) & $86,89 \%$ & $103,53 \%$ \\
\hline Non Performing Financing (NPF) & $4,74 \%$ & $3,02 \%$ \\
\hline Net Operating Margin (NOM) & $0,57 \%$ & $1,96 \%$ \\
\hline Capital Adequacy Ratio (CAR) & $15,57 \%$ & - \\
\hline Rasio BOPO & $96,74 \%$ & $82,15 \%$ \\
\hline Return on Asset (ROA) & $1,10 \%$ & $1,85 \%$ \\
\hline Number of Account TPF & 15,488 million & 3,033 million \\
\hline Number of Financing Customers & 3,361 million & 0,440 million \\
\hline $\begin{array}{l}\text { Equivalent Rate of Return on Time } \\
\text { Deposit } 12 \text { months }\end{array}$ & $6,48 \%$ & $6,84 \%$ \\
\hline
\end{tabular}

Source: Financial Service Authority-OJK, Sharia Banking Statistics (processed)

Based on Table 4.4 above it can be seen that from the aspect of BUS business activity shows better performance than UUS, seen from Total Assets, Deposits, and Financing the average growth rate is higher, also from service side BUS has 15.488 million customers and 3.361 million DPK financing customers, while UUS serves as many as 3,033 million DPK customers and as many as 0.440 million financing customers. From the implementation of BUS intermediation function better than UUS seen from the FDR BUS rate of 86.89 is in healthy condition (healthy tolerance between $78 \%$ - 92\%), while the FDR UUS of $103.53 \%$ exceeded the tolerance limit and potentially threat of liquidity risk. In terms of profitability UUS better than the BUS is seen from the growth rate of $0.16 \%$ profit, NOM ratio $1.96 \%$, and ROA $1.85 \%$ UUS higher than the BUS. This is relevant to UUS efficiency level better than BUS shown by BOPO UUS of $82.15 \%$, while BOPO BUS of $96.74 \%$. In terms of management of productive assets, the UUS is better than BUS shown by the NPF UUS ratio of $3.024 \%$ lower than the BUS NPF of $4.74 \%$. Also in terms of providing returns for customers UUS better than the BUS, which is shown with the equivalent UUS yield rate of $6.84 \%$ greater than the BUS yield of $6.48 \%$.

\subsection{Challenges Facing by Sharia Banking}

In line with the national sharia banking development plan, it is formulated and defined the vision of the national sharia banking, namely: "Creating a national sharia banking that contributes significantly to sustainable economic growth, equity development and financial system stability and high competitive", which later described in the form of direction policies and work programs and implementation time plan. The policy directions include: 1) strengthening policy synergies between authority and government and other stakeholders; 2) strengthening capital and business scale and improving efficiency; 3) improving funding structures to support 
expansion of financing segments; 4) improving service quality and product diversity; ) improve the quantity and quality of human resources and IT and other infrastructure, 6) increase community literacy and preference, and 7) strengthen and harmonize regulatory and supervisory.

\section{Conclusion and Recommendation}

Based on several studies that have been done can be concluded that the UUS spin-off policy as mandated by the Act has been implemented by some Conventional Commercial Bank UUS, although the amount is still small, so that the acceleration of syariah banking development and target market share is not as expected. However, if seen from the performance of BUS in general is better than UUS, especially in terms of growth of business activities and operational aspects.

Therefore, it is necessary to continue efforts for the development of sharia banking by various parties, banking practitioners, banking authorities (BI, OJK), academics, customers, clerics and community leaders, through various educational activities, socialization to improve understanding and community commitment to the development of sharia banking, so that in turn will be more perceived benefits by the wider community.

Facing the challenges ahead in order to maintain the continuous growth of sharia banking, it is necessary to implement the following policy strategies:

* If efforts to accelerate the growth of UUS assets are difficult, then the option that can be done is to approach using existing legal entity or by forming a new legal entity.

* Another option that can be done by UUS is to merge existing UUSs to achieve a 50\% portion of its parent BUK assets. This is very possible to do, especially UUS Regional Development Bank which currently amounts to 14 pieces, with the following scenarios:

- Merger of 5 (five) UUS BPD in Sumatra, among others: UUS BPD North Sumatra, UUS BPD Riau and Riau Islands, UUS BPD Jambi, UUS BPD West Sumatra (Bank Nagari), UUS BPD Sumsel Babel to Sharia Commercial Bank (BUS) Sumatera (Bank Syariah Sumatera), with total assets as of December 31, 2016 amounting to $\mathrm{Rp} 7.5$ trillion.

- Merger of 4 (four) UUS BPD in Java, among others: UUS BPD DKI, UUS BPD Central Java, UUS BPD DIY, and UUS BPD East Java became Sharia Commercial Bank Jawa (Bank Syariah Jawa), with total assets as of December 31 of $\mathrm{Rp} \mathrm{5,8} \mathrm{trillion.}$

- Merger of 3 (three) UUS BPD Kalimantan and 1 (one) UUS BPD Sulawesi, among others: UUS BPD South Kalimantan, UUS BPD West Kalimantan, and UUS BPD Kalimantan, and UUS BPD South and West Sulawesi became BUS Kalimantan (Bank Syariah Kalimantan ), with total assets of Rp 4.8 trillion.

- Need continuous support from the government in efforts to develop sharia banking through various provisions and regulations in the process of spin-off UUS so as not to burden the financial side for both the parent bank and UUS which later became the new Sharia Commercial Bank.

\section{References}

Alim, Muhammad Nizarul (2011), Muhasabah Keuangan Syariah, Aqwam Media Profetika, Solo. Antonio, Muhammad Syafi'i (2005), Bank Syariah: Dari Teori ke Praktik, Gema Insani Press, Jakarta.

Bank Indonesia (2017), Kajian Stabilitas Keuangan No. 28, Departemen Kebijakan Makroprudensial Bank Indonesia, Jakarta.

(2012), Kajian Model Bisnis Perbankan Syariah, Direktorat Perbankan Syariah Bank Indonesia, Jakarta.

Geersing, Bernard (2007), "What Creates More Value: Equity Carve-Outs Versus Spin-Off”, Faculty of Economics and Business Administration Free University of Amsterdam.

Hilman, Iim (2016), “The Factors Affecting Mudharabah Deposit of Sharia Banking in Indonesia”, International 
www.cribfb.com/journal/index.php/ijibfr International Journal of Islamic Banking and Finance Research Vol. 2, No. 2; 2018

Journal of Business and Management Invention, Volume 5, Issue 8 Agustus 2016, www.ijbmi.org.

Hutabarat, Jemsly dan Martani Huseini (2012), Strategi, Pendekatan Komprehensif dan Terintegrasi, Penerbit Universitas Indonesia UI-Press, Jakarta.

Johnson, Gerry and Kevan Scholas (1997), Exploring Corporate Strategy, Fourth Edition, Prentice Hall, New York.

Karim, Adiwarman A. (2010), Bank Islam: Analisis Fiqih dan Keuangan, RajaGrafindo Persada, Jakarta.

Mintzberg, Henry (1994), The Rise and Fall of Strategic Planning, Harvard Business Press, London.

Otoritas Jasa Keuangan (2015), Roadmap Perbankan Syariah Indonesia 2015-2019, Departemen Perbankan Syariah, Jakarta.

---------(2017), Laporan Profil Industri Perbankan Triwulan IV 2016, Departemen Pengembangan Pengawasan dan Manajemen Krisis, Jakarta.

Sugiyono (2012). Metodologi Penelitian Kualitaitif dan Kuantitatif. Penerbit Alfabeta, Bandung.

Susanto, AB. (2014), Manajemen Strategik Komprehensif, Penerbit Erlangga, Jakarta.

Sulistiowati (2009), Keterkaitan Induk dan Anak Perusahaan dalam Konstruksi Perusahaan Kelompok dan Implikasi Kepada Pihak Ketiga di Indonesia, Program Pascasarjana Fakultas Hukum UGM, Yogyakarta.

Tisnawan, Hilman, "Spin-Off, Konstruksi Hukum dalam Upaya Penguatan Struktur Perbankan Nasional", Buletin Hukum Perbankan dan Kebanksentralan, Vol. 7 No. 1 Januari 2009, Bank Indonesia, Jakarta.

Umam, Khotibul \& Veri Antoni (2015), Corporate Action Pembentukan Bank Syariah (Akuisisi, Konversi, dan Spin-Off), Gadjah Mada University Press, Yogyakarta.

Wheelen, Thomas L., and J. David Hunger (2015), Strategic Management and Business Policy, Fourteenth Edition, Pearson Education Limited, England.

\section{Copyrights}

Copyright for this article is retained by the author(s), with first publication rights granted to the journal.

This is an open-access article distributed under the terms and conditions of the Creative Commons Attribution license (http://creativecommons.org/licenses/by/4.0/). 